\title{
Access to Firearms as an Element of Political Positioning of the Democratic Party and the Republican Party during the 2016 US Presidential Elections
}

\author{
Dostęp do broni palnej jako element pozycjonowania Partii Demokratycznej \\ i Partii Republikańskiej w USA podczas wyborów prezydenckich w 2016 roku
}

\section{- Abstrakt •}

Celem artykułu jest wskazanie sposobu pozycjonowania się Partii Demokratycznej i Partii Republikańskiej w zakresie dostępu do broni palnej podczas kampanii w wyborach na prezydenta USA z 2016 roku. Przedmiotem badań są dokumenty programowe obu partii oraz wypowiedzi kandydatów na prezydenta USA w kampanii wyborczej, dotyczące dostępu do broni palnej. Metodą pracy jest analiza zawartości. Na podstawie przeprowadzonych badań wskazane zostały liczne podobieństwa i różnice produktów politycznych oraz sposoby pozycjonowania się partii w kontekście dostępu do broni palnej. Rezultatem badań jest wskazanie istotności dostępu do broni palnej jako produktu politycznego szczególnie silnie dzielącego społeczeństwo amerykańskie. Wartością dodaną pracy jest wskazanie znaczenia dostępu do posiadania broni palnej jako istotnego elementu kultury politycznej, wpływającego na rynek polityczny.

\section{- Abstract •}

The aim of the paper is to identify and describe the policy positioningof the Democratic Party and the Republican Party as concerns access to firearms duringthe 2016 presidential election in the USA. The material analyzed includes official political platforms of both parties and statements of presidential candidates on access to firearms issued during the presidential campaign. The main research method used is content analysis. Based on the conducted analysis, numerous differences and similarities were identified between elements of the political product of "Firearms access" as well as in the (self) positioning of the two parties in relation to the issue. The results point to the significance of the problem of access to firearms as a political product strongly stratifying the American society, a true line of partisan divide. The added value of the article is highlighting the importance of the issue of firearms access in the American political culture, markedly influencing the American political market. 
Słowa kluczowe: wybory prezydenckie w USA 2016; marketing polityczny; pozycjonowanie się; dostęp do broni palnej; broń palna w kulturze politycznej
Keywords: 2016 US presidential elections; political marketing; positioning; access to firearms; firearms in political culture

The aim of the paper is to identify and describe the policy positioning of the Democratic Party and the Republican Party as concerns access to firearms during the 2016 presidential election in the USA. The material analyzed includes official political platforms of both parties and statements of presidential candidates on access to firearms issued during the presidential campaign. The first chapter presents the significance of the issue of firearms in the American political culture; the second chapter offers analysis of the political platforms and public speeches of the two presidential candidates. In the third chapter, the author carries out a comparison of positions of both parties relative to this issue. The article wraps up with a short conclusion that includes also maps illustrating the stratifying power of access to firearms as a political product.

The research method used in the paper is content analysis. Based on the conducted research, numerous differences and similarities were identified in the political product "Access to firearms" as well as in the positioning of the parties on this issue. The results point to the significance of the problem of access to firearms as a political product strongly stratifying the American society. The added value of the article is highlighting the importance of the issue of forearms access in the American political culture, markedly influencing the American political market. The material taken into consideration as part of the research carried out did not include public speeches of other important figures in the Democratic and Republican Parties - the focus was on presidential candidates as embodiment of the offer contained within the respective political platforms of these parties.

\section{Introduction. Role of Firearms in the Political Culture of American Society}

Over the 200 years of USA history, firearms have always been playing an important role. Firearms appeared in the current territory of the United States together with European explorers. In 1513 and 1521, the expedition of Juan Ponce de Leon used arquebuses on the Floridian peninsula (Davis, 2003, p. 44). In early $17^{\text {th }}$ century, matchlock muskets were used and black powder warehouses were built (McBee, 2009, p. 17) in the oldest British settlement in Jamestown, Virginia. Wheel- 
lock rifles formed part of equipment of the crew of the Mayflower ship (Goldstein, 2001, pp. 2-5). Firearms played a significant role in the process of colonization of the American continents. The ability to hit targets from a large distance facilitated hunting, necessary to survive harsh winters. Firepower of the modern guns was a great advantage in defense against the most dangerous animals. Simultaneously, the use of firearms played a fundamental role in defending lives and properties against criminals, Indian attacks - as well as in organization of sporting activities. Guns became a constant companion in the everyday life of the British colonists, in particular those inhabiting the frontier regions (Riley, 2012, pp. 1685-1693). Pioneers spearheading the territorial expansion of the first colonies lived under constant and serious threats. In order to survive on the frontier, resourcefulness as well as shooting skills were needed. One of the leading theoretical works explaining the role of such frontier mindset in development of the American democracy was authored by Frederick Jackson Turner This American researcher proved the existence of a relationship between the challenges of living at the frontier and development of a democratic political culture (Turner, 1923, pp. 11-42). Shifting of the western frontier contributed to the evolution of the American political culture. Egalitarianism, individualism, libertarianism, individual approach to security measures and social acceptance for the use of justified violence when threatened became inherent elements of the colonists' political culture. Thus at the dawn of the American statehood, firearms were one of the most important, physical artefacts of the everyday life - and the American political culture.

The rise of the United States was connected with an armed secession of thirteen colonies from the English monarchy. The War of Independence highlighted the role of firearms as the main weapon on battlefields of the modern armed conflicts. It is worth pointing out that shooting skills of the Americans were one of the leading factors in their victory over the regular British army (McIntyre, 2012, p. 11). High significance of firearms possession in the hierarchy of values was stressed in the Second Amendment, adopted in 1791, stipulating that: "A well-regulated militia, being necessary to the security of free state, the right of the people to keep and bear arms, shall not be infringed" (U.S. Government Publishing Office, 2017). This points to the fundamental role of civilian possession of firearms in ensuring security of a free state. The phrase "militia" refers to armed formations created in a bottom-up movement in this case. The Second Amendment guarantees both the right to possess and to carry weapons and provides for inviolability of those rights. Influenced by the philosophy of the Enlightenment (Mansfield, 2003, pp.4-26), the Founding Fathers endeavored to establish a state without a regular army, where armed citizens defended the constitutional order, especially 
as concerned safeguarding their rights and liberties when faced with a tyrannical government. Interpretations of the Second Amendment varied in response to incidents of unrest and disturbances in the functioning of the society (Kazalbasch, 2003, pp. 2-15). The legal framework regulating access to firearms was developed as a reaction to important events or processes, including four successful assassination attempts against U.S. Presidents, development of organized crime, shootings and terrorist threats. Access to firearms for the Afro-Americans was also part of the abolition movement demands. Overall, the significance of firearms access in the American political culture goes beyond the matter of self-defense and, instead, is connected with notions of liberty, independence and security and safety.

Nowadays, the United States of America boast the largest number of civilian-owned firearms worldwide. The estimated number of firearms in the USA ranges from 270 to 310 million (Ingraham, 2018). It means that there are on average 89 guns per every 100 Americans. From 1972 to 2017, the share of gun-owner households rose from $37 \%$ to $47 \%$. In the 2001-2017 period, the average share of those households was 41\% (Statista.com, 2018). It should be noted that the data on number of possessed firearms per household shows huge discrepancies, with some reporting ownership of hundreds of guns. The most important organization gathering firearm owners is the National Rifle Association (National Rifle Association webpage, 2018), while numerous other civic organizations are seeking stricter control over access to firearms in the USA.

\section{Theoretical Background of Political Marketing}

Political marketing was developed in mid-20 $0^{\text {th }}$ century in the United States of America. Some researchers indicate that the decisive moment was the presidential campaign of Dwight Eisenhower in 1952 (Mazur, 2004, pp. 12-13). Because of the increasing number of TV sets, the electoral staff of Dwight Eisenhower developed a political strategy taking advantage of this new, unilateral, mass channel of political communication - i.e. TV broadcasts. The political campaign was planned in detail, in particular in terms of political speeches in states with important numbers of electoral votes. There is no doubt that the development of political marketing coincided with the development of mass culture (Wojtkowski, 2010, pp. 8-33). Thanks to the use of new communication tools, standarized image of a candidate could reach the entire society; all in all political marketing opened up wider opportunities for the public to get to know and choose to support a particular candidate. 
Political marketing is defined in a variety of ways. Among numerous approaches to defining the term, one can distinguish approaches referring to political marketing as social engineering and those viewing it more broadly, as an exchange process. The present paper focuses on two elements selected from this variety of definitions, underlining its role in shaping electoral preferences and as a means to clarify a party position in the political market. According to Robert Wiszniowski, political marketing is "a set of techniques used to create changes in behavior of political entities and citizens in the area of political competition, within the specified and long-term processes" (Wiszniowski, 1998, p. 230). The definition of A. Lock and P. Harris describes political marketing as encompassing processes of exchange between political entities and their surroundings and between themselves, in particular concerning policy positioning and communication, goals and methods of implementing their strategy. Thus understood, the term covers also research on attitudes, awareness and reactions of target groups, as well as laws and movements by external regulators contributing those processes (Lock, Harris, 1996).

One of the most widespread concepts in marketing is the so-called Marketing Mix. This theoretical approach was presented in 1960 by J.E. McCarthy and defines four crucial elements making up all marketing efforts: product, price, placement, promotion (Sobczyk, Celoch, 2012, p. 22). The 4P concept presents marketing as communication exchange between an enterprise and a client. On the enterprise side, communication focuses on the product being able to meet clients' needs and its availability at an acceptable price. Proper distribution and promotion are equally important, as they determine whether and how a product can be delivered to clients, as well as scope of information provided (specification) and in the end perception of the key customer value offered by a given good. Development of the 4P model resulted in its expansion to a 7P model (Sobczyk, Celoch, 2012, p. 23), pointing out also people, processes (influencing the perception of the final product) and physical evidence (connected with the image of a given enterprise, its perception as a quality manufacturer/provider) as key building blocks of marketing. Due to economic and social changes occurring in the second half of the $20^{\text {th }}$ century, the marketing frameworks focusing on enterprise side of the equation were increasingly criticized. In 1990, Robert Lauterborn proposed the 4C approach (Sobczyk, Celoch, 2012, p. 22), focusing instead on the side of customers, clients. Product was replaced by customer value, price by costs borne by clients to satisfy their needs. The $4 \mathrm{C}$ approach highlights also buyers' need for a certain level of convenience while making a purchase and the role of bilateral communication (the fourth "C") between clients and enterprises. Transferring the $4 \mathrm{P}$ and $4 \mathrm{C}$ frameworks to the field of political science helps to identify and cluster 
terms important for marketing in the political domain (such as public figures, political interest groups, projects and ideas, political support, presentation and promotion activities, reaching clients during political campaigns) (Wiszniowski, 2002, p. 50). Table number 1 shows a comparison of the $4 \mathrm{C}$ and $4 \mathrm{P}$ approaches along with their "translation" into the domain of political sciences.

Table 1. Crucial elements of political marketing

\begin{tabular}{|c|c|c|}
\hline 4P & 4C & Political marketing \\
\hline Product & Customer value & $\begin{array}{c}\text { Public figures, groups, } \\
\text { projects, ideas }\end{array}$ \\
\hline Price & Cost & $\begin{array}{c}\text { For example: voting decision } \\
\text { or political support }\end{array}$ \\
\hline Place(ment) & Convenience & $\begin{array}{c}\text { Reaching the recipients } \\
\text { during a political campaign }\end{array}$ \\
\hline Promotion (Unilateral) & Communication (Bilateral) & $\begin{array}{c}\text { Promotion and presentation } \\
\text { activities, involving clients } \\
\text { in promotion }\end{array}$ \\
\hline
\end{tabular}

Source: own work based on R. Wiszniowski, 2002, p. 50.

The necessary condition for political marketing is existence of a defined political market. The US political market is characterized by decreasing size of electorate consistently supporting either the Democratic or the Republican party observable for well over 25 years (Fiorina, 2016, pp. 3-9). The increasing share of Americans not voting consistently for one side of the partisan divide influences the political marketing strategies of the parties in question. However, despite lack of steadiness in voting preferences, the electorate votes are still divided between the Democrats and the Republicans. The share of politicians belonging to any other party (or not party-affiliated) is still marginal. Thus, the political offer available on the U.S. political market is rather narrow and allows to categorize the market as a closed one (Dobek-Ostrowska, 2006, p. 235). Because of significant and growing share of voters demonstrating inconsistent (from party caucus perspective) voting preferences, the American market should be seen as offering large opportunities for political marketing - in order to successfully affect voting behaviors, a proper marketing strategy is necessary. The strategic triad in marketing, also known as STP marketing (Krasowski, 2014, pp. 171-172), is a three-stage process, from client segmentation, through targeting of certain groups and positioning of the offer.

Hence, it is important to indicate differences between the political products of both parties and the manner of their delivery and presentation. In addition, 
one should segment the American society in terms of possible compatibility of the respective partisan offers with potential clients, dividing them into target groups. Content analysis of political platforms of the Democratic and the Republican Parties along with analysis of political speeches of presidential candidates of both parties allows to determine how the political offer is being positioned and to carry out a comparative analysis.

\section{Access to Firearms as a Political Product Forming Part of the Democratic and the Republican Political Offer}

The United States are an example of a two-party political system (Sobolewska-Myślik, 2004, p. 177). The Democratic Party and the Republican Party have constituted the two main political organizations since the 1850s. It is worth pointing out that the political differences between the Democrats and the Republicans has even deepened since the time of cultural revolution, with the Democratic Party emerging as socially liberal and the Republican Party - as conservative (Miller, Schofield, 2008, pp. 433-440). Both parties discuss access to firearms as a political product within their platform. As a result of a different ideologies of the parties, there are significant differences in the characteristics of this "product", intended to sway certain groups to vote for one of the parties. The specific partisan position as concerns firearms was presented during speeches delivered before and during the presidential campaigns by Hilary Clinton, presidential candidate of the Democratic Party, and the candidate of the Republican Party, Donald Trump.

In its political platform for 2016-2020, the Democratic Party included the issue of access to firearms under the health care $\&$ security category (Democratic Party website, 2016). The Democrats aimed, as was explained, to curb gun-related violence and thus advocated tightening of gun possession regulations in terms of the control process. The Democratic Party wanted to ban possession of assault weapons and firearms with large capacity magazines without disputing the constitutional law to arry arms as such. The Democrats listed among essentialgoals and competences of the Bureau of Alcohol, Tobbaco, Firearms and Explosives (Democatic Party website, 2016) also prevention of access to firearms by terrorists, domestic abusers, felons charged with serious crimes or mentally disabled people. By increasing the budget of the Centers for Disease Control and Prevention, Democrats wanted to enhance the effectiveness of the organization.

The Republican Party in its political platform framed the issue of access to firearms in terms of restoration of the government's position as a warden and enforcer 
of the constitution (GOP website, 2016). In the paragraph concerning the Second Amendment, the Republicans equated the right to possess and carry weapons with a God-given right to self-defense, including ensuring safety of houses, loved ones and the society as a whole. The Republican Party clarified its intent to stop judges with liberal views from being appointed onto the Supreme Court bench. The Grand Old Party intended to defend the constitution-granted right to carry arms and support the states in implementing this unlimited constitution-based model of firearm access on their territories. The Republicans opposed any attempts to limit this right, especially those based on magazine capacity thresholds, through an assault weapons ban or what they termed frivolous law suits against firearms producers and dealers (GOP website, 2016). The Republican Party declared its desire to abolish gun licensing and registration of law-abiding owners of firearms and ammunition, and to not in any manner return to the assault weapons ban.

Hilary Clinton delivered a speech concerning access to firearms in Manchester, New Hampshire, on October 5, 2015 (CBSN YouTube, 2015). The public appearance clarified the Democrat's position on the issue, emphasizing the negative influence of firearms on the life and health of Americans. Clinton pointed to cases of fatal shootings of children and quoted statistical data on number of people wounded or killed due to gun violence. The Democrat stated that gunshots were the leading cause of death of young Afro-Americans, the second most frequent cause of death of young Latinos and the fourth in the case of young Whites. The narrative of the Democratic Party presidential candidate contained phrases equating guns with disease; ex. in order to stop the "epidemic of gun violence" (CBSN YouTube, 2015), Clinton proposed conducting obligatory social interviews about everyone intending to purchase a firearm. The Democrat stressed the need to close the legal loopholes allowing for sale of firearms without previous check of criminal record of a purchaser (CBSN YouTube, 2015). Developing a common understanding of the responsible way of keeping firearms within households was also a significant part of the speech. In the programmatic platform, access to firearms was banned inter alia for domestic abusers. Ordinary citizens - i.e. the public - as well as public figures were engaged in promoting the platform, with appearances from the mother of a shot child as well as the former member of Congress, Richard "Dick" Swett, who cited a letter from Ronald Reagan on the need to support legislative initiatives banning access to assault weapons (CBSN YouTube, 2015).

Donald Trump presented his position on access to firearms on May 20, 2016, during the National Rifle Association convention in Louisville, Kentucky (CNN YouTube, 2016). The narration of the candidate was consistent with the political platform of the Republican Party, viewing right to bear arms as protected by con- 
stitutional law, as well as under the broad umbrella of right to self-defense. Trump pointed out an example of Paris as a city under a terrorist threat where access to firearms was hindered (CNN YouTube, 2016). Both in Paris and in San Bernardino, the victims of terrorist attacks were defenseless, because of lack of right to carry weapons. The candidate referred to statistics on the number of firearm licenses and use of firearms in self-defense (CNN YouTube, 2016). The important aspect of the Republican Party offer was abolishing gun-free zones and appointing Supreme Court judges who would faithfully implement the constitutional order, especially the Second Amendment. Donald Trump underlined the correlation between possession of firearms and the rule of law. Trump stressed how proud he was of having the NRA's support and promised to defend it and its reason of existence (CNN YouTube, 2016).

During all three presidential campaign debates, Hilary Clinton as well as Donald Trump referenced the matter of firearms access. The narratives of both candidates were consistent with the political platform of their respective Parties. In the first debate, Hilary Clinton breached the issue of access to firearms as the first one (NBC News YouTube, 2016). Her narration was similar to the one delivered during the speech in New Hampshire. Clinton emphasized the necessity of prohibiting access to firearms for people posing a threat to others, and of conducting community interviews for all prospective gun owners. The Democratic candidate focused on links between her opponent and the firearms producers lobby, which allowed to overturn the ban on civilian possession of assault weapons (NBC News YouTube, 2016). According to Clinton, this situation complicated the lives of police officers, especially during interventions. The Democrat summarized the speech by postulating a ban on access to firearms for people suspected of connections with terrorism, persons of interest to various agencies or national services or fugitives (NBC News YouTube, 2016). Donald Trump in turn used the example of Chicago as a city where, despite previous restrictions on gun access, killings involving firearms were widespread (NBC News YouTube, 2016). Emphasizing the necessity of reintroducing the rule of law and public order, Trump declared his intent to take guns away from criminals. Highlighting the alignment between his stance and that of the NRA, the Republican reiterated that the Association has a similar intention of banning access to firearms for these particular groups. In the second presidential debate, the issue of access to firearms was part of statements concerning the reform of the judiciary system. Donald Trump declared the Republicans would strive to appoint to the Supreme Court only judges fully respecting the Second Amendment, what meant judges opposing the democratic party line (NBC News YouTube, 2016). Hilary Clinton reiterated the Democrats' intent 
to respect constitutional law, while insisting on introduction of community interviews and closing of legal loop-holes (NBC News YouTube, 2016). In the third presidential debate, the issue of access to firearms was mentioned again as part of discussion of the judiciary system reforms. Trump indicated the Supreme Court as a guarantor of realization of his Party policy position on firearms. The Republican warned that a possible victory of Clinton would result in the true meaning of the Second Amendment being compromised. The Democratic candidate responded by quickly summarizing the significance of firearms in the history of USA; she stated that there was no conflict between saving lives and still respecting the constitutional law. Trump mentioned also Clinton's dissatisfaction with the decision of the Supreme Court on lack of necessity for regulating conditions in which firearms were kept within households (NBC News YouTube, 2016). Hilary Clinton confirmed her disagreement with this decision and focused on the numerous cases of harm to children due to unsecured storage of weapons at homes, reiterating the threats inherent in improper storage of these dangerous items. In the further part of the debate, Clinton shortly mentioned also banning access to firearms for criminals (NBC News YouTube, 2016).

Comparison of the offer of the Democratic Party and the Republican Party as concerns access to firearms as a political product shows some similarities, but differences prevail. The similarities are the product type - how the issue is defined or summarized, its "heading" - circumstanced in which the offer was presented and the planned methods of ensuring implementation of the Party position in this respect. The differences lay in the condition necessary for bring the given "product" to life, in specific features of the products and values it offers to the public. Table 2 below shows the comparison of the Democratic and Republican positions on access to firearms.

Table 2. Access to firearms as an element of the Democratic Party and the Republican Party platforms

\begin{tabular}{|c|c|c|c|}
\hline Lp. & $\begin{array}{c}\text { Object } \\
\text { of comparison }\end{array}$ & $\begin{array}{c}\text { Offer } \\
\text { of the Democratic Party }\end{array}$ & $\begin{array}{c}\text { Offer } \\
\text { of the Republican Party }\end{array}$ \\
\hline 1 & Political product & Access to firearms & Access to firearms \\
\hline 2 & $\begin{array}{c}\text { Condition for } \\
\text { implementation of } \\
\text { this product version }\end{array}$ & $\begin{array}{c}\text { Voting for the presidential } \\
\text { candidate of the Democratic } \\
\text { Party }\end{array}$ & $\begin{array}{c}\text { Voting for the presidential } \\
\text { candidate of the Republican } \\
\text { Party }\end{array}$ \\
\hline 3 & Implementation & $\begin{array}{c}\text { Increasing budget of the ATF, } \\
\text { establishing organization } \\
\text { in opposition to the NRA }\end{array}$ & $\begin{array}{c}\text { Appointing judges } \\
\text { to the Supreme Court } \\
\text { in line with Party platform, } \\
\text { supporting the NRA }\end{array}$ \\
\hline
\end{tabular}


Tab. 2 - cont.

\begin{tabular}{|c|c|c|c|}
\hline Lp. & $\begin{array}{c}\text { Object } \\
\text { of comparison }\end{array}$ & $\begin{array}{c}\text { Offer } \\
\text { of the Democratic Party }\end{array}$ & $\begin{array}{c}\text { Offer } \\
\text { of the Republican Party }\end{array}$ \\
\hline 4 & $\begin{array}{c}\text { Presentation and } \\
\text { promotion }\end{array}$ & $\begin{array}{c}\text { The offer was presented } \\
\text { during debate concerning } \\
\text { access to firearms and during } \\
\text { presidential campaign debates }\end{array}$ & $\begin{array}{c}\text { The offer was presented } \\
\text { during debate concerning } \\
\text { access to firearms and during } \\
\text { presidential campaign debates }\end{array}$ \\
\hline 5 & $\begin{array}{c}\text { Specification of the } \\
\text { product }\end{array}$ & $\begin{array}{c}\text { Ban of assault weapons, access } \\
\text { of people posing any type of } \\
\text { threat prohibited, obligatory } \\
\text { community interviews }\end{array}$ & $\begin{array}{c}\text { Possession of assault weapons } \\
\text { permitted, no need } \\
\text { for community interviews, } \\
\text { no limits on capacity } \\
\text { of magazines }\end{array}$ \\
\hline 6 & Value of the product & $\begin{array}{c}\text { Decreasing number of people } \\
\text { harmed by guns, low possibility } \\
\text { of firearms purchase } \\
\text { by dangerous people, } \\
\text { development of awareness } \\
\text { in terms of safe storage } \\
\text { of firearms }\end{array}$ & $\begin{array}{c}\text { Effective self-defense achievable } \\
\text { for a wider segment } \\
\text { of the public, sense of freedom, } \\
\text { ensuring compliance } \\
\text { with the Second Amendment }\end{array}$ \\
\hline
\end{tabular}

Source: own work.

\section{Similarities and Differences in Policy Positioning of the Democratic Party and the Republican Party}

In order to compare policy positioning (Krasowski, 2014, p. 171) of the Democratic and the Republican parties on firearms access, one should include perspective on segmentation and targeting of clients in this comparison (Krasowski, 2014, p. 171). On the basis of the conducted analysis, it was possible to divide the American society into client groups constituting relevant targets for the offer of each of the parties.

This segmentation of the American society in terms of support for the Democratic Party or the Republican Party approach to access to firearms is linked to possession of firearms. In 2016, nearly $40 \%$ of households were inhabited by at least one owner of a firearm (Statista, 2018).

The offer of the Democrats, disallowing purchase of firearms by people suspected of connections with terrorist groups, persons of interest to various government agencies and services, domestic abusers or people with serious mental disorders is intended mainly for people not owning a gun. It is, after all, in the interest of non-owners of firearms (defenseless in case of aggression by an armed 
person) to ensure people that may pose a threat cannot carry weapons. The offer of the Democratic Party was also resonating with those close to victims of shootings, both wounded and killed as a result of gun-related violence. It is worth pointing out that in the United States around 33000 people are shot dead every year (Center for Disease Control and Prevention, 2016). The American society is made up in $12,4 \%$ of Afro-Americans, $61,72 \%$ are Whites and circa $17,7 \%$ are Latino (Statista, 2018). The offer of the Democratic Party focusing on increasing safety could also be attractive for Afro-American and Latino citizens as these groups are particularly vulnerable.

Thus within the target group of the Democratic Party we can distinguish advocates of restrictions on access to firearms, non-owners of guns, relatives of people harmed by gun violence, supporters of the assault weapons ban, Afro-Americans and Latinos. Inclusion in this targeting of individuals and representatives of institutions bearing various costs associated with gun violence, such as real estate owners and the health insurance sector, is also justified.

In terms of the Republican offer, its main value lies in freedom of choice in purchasing and keeping of firearms, as well as compliance with the spirit of the Second Amendment spirit as related to the possession of firearms - clearly resonating with gun owners, but not only. Here the group of potential clients consists of firearms owners, advocates of the literal meaning of the Second Amendment, relatives of people who effectively used firearms for self-defense, WASPs, people interested in purchase of an assault weapon. It is important to indicate weapons producers and dealers of firearms, as well as certain professional groups - such as shooting instructors - as part of the targeted segments.

In the 2016 presidential election, the Democratic Party positioned itself as the side proposing a reasonable compromise between the right to firearms access and ensuring safety of citizens. The distinctive element of the Democratic political platform is the increased safety resulting from postulated regulations preventing people posing a threat to society from gaining access to guns. The offer of the Democratic Party is supplemented by proposal of developing (and regulating) best practices in storage of firearms. The Democratic product can be perceived as a valuable solution holding back serious social threats.

The Republican Party on the other hand positioned itself as an uncompromising defender of the constitutional order, especially the Second Amendment. The distinctive element of the Republican offer is the sense of personal liberty, freedom of purchasing and carrying weapons granted to law-abiding citizens, without any limitation. The political product of the Republicans included also ensuring inviolability of the Second Amendment through appointment to the Supreme Court 
only of judges defending the constitutional right of bearing firearms.

The political product of the Democratic Party references the term "safety" in its negative definition, based on lack of a threat. When referenced by the Republican Party in the context of access to firearms, the term "safety" was used in its positive definition - situation with high probability of survival and high level of comfort thanks to defensive capabilities gained through the right to carry arms.

\section{Conclusions}

Access to firearms remains the most stratifying factor on the American political market, dividing people into clients of a given party. Within households not owning firearms, Hilary Clinton was supported by a majority of voters in 47 states (excluding Wyoming due to lack of data and West Virginia where the majority supported Donald Trump). In the case of households with at least one gun-owner, Donald Trump was supported by the majority of voters in 48 states (excluding Vermont where such households also supported Hilary Clinton). Map 1 below shows the support of gun-free households for Hilary Clinton (blue colour), while Map 2 presents how gun-owning households voted in favor of Donald Trump (red color).

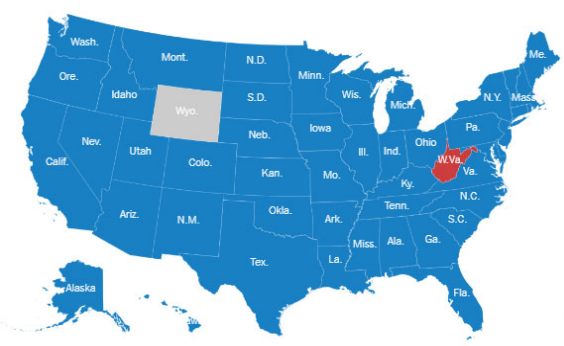

Map 1.

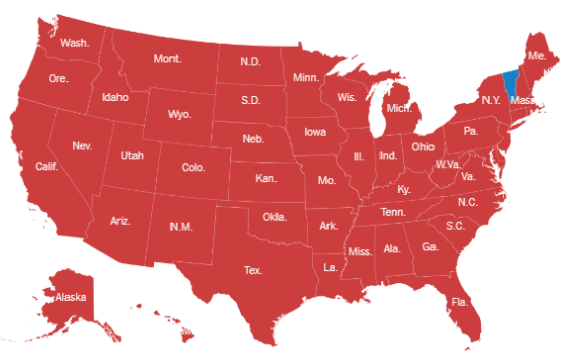

Map 2.

Source: Gun Ownership Partisan Divide, https:/www.nytimes.com/interactive/2017/10/05/upshot/ gun-ownership-partisan-divide.html.

On the American political market, access to firearms is one of the most significant political products determining a voter's position along the partisan divide. Every political group intending to create an attractive offer for an American client must consider what is its position on access to firearms as a political product. No 
significant political entity in the USA is proposing a wider ban on access to firearms. During the 2016 presidential campaign, the Democratic Party positioned itself around ensuring safety of citizens through some limits on free access to weapons, while the Republican Party presented itself as staunch defender of the constitutional right to bear arms. Thus in the 2016 presidential elections the difference in positioning of the two main political groupings lay in the choice between more safety-conscious conditions of purchasing and possessing firearms and the sense of personal freedom, including freedom to possess all kinds of weapons. However, liberty and safety are not incompatible, so the hard division between the two political options is not so clear-cut as it seems. Still, in the political culture of the American society, the issue of civilian possession of firearms has been, is and will continue to be a key determinant of partisan support.

\section{References:}

Centers for Disease Control and Prevention website. (2019). Retrieved from: https://www. cdc.gov/.

Davis, T.F. (2003). History of Juan Ponce de Leon Voyages to Florida. Wisconsin: Wisconsin Historical Society.

Democratic Party website. (2019). Retrieved from: https://www.democrats.org/.

Dobek-Ostrowska, B. (2006). Komunikowanie polityczne i publiczne. Warszawa: Wydawnictwo Naukowe PWN.

Fiorina, M.P. (2017). The 2016 Presiedential Election - An Abundance of Controversies. Hoover Institute. Retrieved from: https://www.hoover.org/sites/default/files/research/ docs/fiorina_webreadypdfupdated.pdf.

Goldstein, K. (2001). Arms \& Armor of the Pilgrims. Retrieved from: http://www.pilgrimhallmuseum.org/pdf/Arms_Armor_of_Pilgrims.pdf.

Ingraham, Ch. (2018). There Are More Guns Than People in United States. Retrieved from: https://www.washingtonpost.com.

Kazalbasch, N. (2003). A Modern Interpretation of the Second Ammendment. Law Forum Journal, 1, University of California.

Krasowski, P. (2014). Pozycjonowanie w kampanii parlamentarnej 2011 roku w świetle wywiadów ze sztabowcami Platformy Obywatelskiej Prawa i Sprawiedliwości, Polskiego Stronnictwa Ludowego oraz Sojuszu Lewicy Demokratycznej. In: M. Cichosz, D. Skrzypiński (eds.). Segmentacja, targeting, pozycjonowanie na rynku politycznym (pp. 171-172). Wrocław: Instytut Politologii Uniwersytetu Wrocławskiego.

Lock, H., Harris, P. (1996). Political Marketing. European Journal of Marketing, 30(10/11), $14-24$.

Mansfield, H.C. (2003). Liberty and Virtue in the American Founding. In: P. Berkowitz, Never Matter of Indifference: Sustaining Virtue in a Free Republic (pp. 4-26). Stanford: Hoover Institution Press. 
Mazur, M. (2004). Marketing polityczny. Studium porównawcze. Warszawa: Wydawnictwo Naukowe PWN.

McBee, S. (2009). The History of the Jamestown Colony: Seventeenth-Century and Modern Interpretations. Mansield: The Ohio State University at Mansfield.

McIntyre, J. (2012). The Role of Riflemen in the Souther Campaings of the American War of Independence. Retrieved from: http://lib.jrshelby.com/mcintyre-riflemen $\% 20 \mathrm{in} \% 20$ the $\% 20$ south.pdf.

Miller, G., Schofield, N. (2008). The Transformation of the Republican and Democratic Party Coalitions in the U.S. Perspectives on Politics, 6(3). Cambridge: Cambridge University Press.

National Rifle Association website. (2019). Retrieved from: https:/home.nra.org/.

Republican Party website. (2019). Retrieved from: https:/www.gop.com/.

Riley, A.R. (2012). Indians and Guns, Vol. 100. Georgetown: The Georgetown Law Journal.

Turner, F.J. (1923). The Frontier in American History. New York: H. Holt and Company. Retrieved from: http://www.bahaistudies.net/asma/the_frontier.pdf.

Sobczyk, G., Celoch, A. (2012). Marketing współczesnej organizacji. In: D. Filar (ed.). Wspótczesny marketing. Skuteczna komunikacja i promocja. Lublin: UMCS.

Sobolewska-Myślik, K. (2004). Partie i systemy partyjne na świecie. Warszawa: Wydawnictwo Naukowe PWN.

Statistica website. Retrieved from: https://www.statista.com.

U.S. Congress Library website. (2019). Retrieved from: https:/www.congress.gov.

Wiszniowski, R. (1998). Marketing polityczny. Koncepcje teoretyczne i praktyka. In: A.W. Jabłoński, L. Sobkowiak (eds.). Studia z teorii polityki (Vol. II, p. 230). Wrocław: Wydawnictwo Uniwersytetu Wrocławskiego.

Wiszniowski, R. (2002). Wprowadzenie do teorii marketingu politycznego. In: A.W. Jabłoński, L. Sobkowiak (eds.). Marketing polityczny w teorii i praktyce. Wrocław: Wydawnictwo Uniwersytetu Wrocławskiego.

Wojtkowski, Ł. (2010). Kultura masowa a marketing polityczny. Przypadek amerykańskich kampanii prezydenckich 2000 i 2004. Toruń: Wydawnictwo Adam Marszałek.

YouTube website. (2019). Retrieved from: https://www.youtube.com/. 